\title{
RANCANG BANGUN MESIN PARUT KELAPA SKALA RUMAH TANGGA DENGAN MOTOR LISTRIK 220 VOLT
}

\author{
Gugun Gundara $^{1 *}$, Slamet Riyadi² \\ 1)Program Studi Teknik Mesin, Fakultas Teknik, Universitas Muhammadiyah Tasikmalaya \\ Jl. Tamansari km 2.5 Gobras, Tasikmalaya Kode pos 46196 Telp. 02652350982 \\ 2)Teknik Mesin Fakultas Teknik Universitas Galuh Ciamis \\ Kampus JL. RE. Martadinata No. 150 Cms TIp. (0265) 776325 \\ gugun@umtas.ac.id'1
}

\begin{abstract}
Abstrak
Proses pemarutan kelapa tenaga yang relatif besar dan kemampuan khusus agar hasilnya baik dan tangan tidak terluka. Untuk mempermudah pemarutan dan menjaga higienitas serta meningkatkan kapasitas pemarutan pada rumah tangga dan industri kecil sudah di buat alat bantu atau mesin parut kelapa banyak mesin parut kelapa di rancang atau di buat dengan berbagai model dan harganya barvariasi. Salah satu rancangan atau desain yang beredar dipasar adalah mesin parut yang menggunakan mesin motor dengan bahan bakar bensin. Mesin ini dirancang sedemikian rupa untuk meningkatkan keselamatan bagi pemakai, mempercepat proses pemarutan kelapa, meningkatkan kapasitas, serta menjaga higienitas dari kelapa parut. Tetapi alat mesin parut kelapa skala rumah tangga dan industri kecil masih relatif mahal. Pada perancangan ini dibuat alat dengan redesain mesin parut kelapa mini untuk mengurangi biaya material dan biaya manufaktur. Melakukan perubahan denga bentuk dan dimensi untuk kerangka dan penyangga. Disamping itu juga perubahan pada komponen mesin dengan motor listrik skala rumah tangga dengan daya 220 volt.
\end{abstract}

Kata kunci: daya, desain, industry, mesin, motor listrik

\section{Pendahuluan}

Tanaman kelapa telah sejak ratusan tahun di kenal di seluruh kepulauan Nusantara. Kelapa merupakan salah satu penghasil bahan makanan yang sangat penting dalam kehidupan rakyat Indonesia. Hal ini dapat dilihat dari kenyataan

bahwa $75 \%$ dari minyak nabati dan $8 \%$ dari konsumsi protein bersumber dari kelapa. Selain itu tanaman kelapa merupakan tanaman serba guna, yang keseluruhan bagiannya dapat dimanfaatkan bagi kehidupan manusia dan menghasilkan keuntungan. Oleh karena itu kelapa mempunyai arti yang sangat penting bagi kehidupan dan perekonomian di Indonesia [1].

Daging buah kelapa merupakan salah satu jenis bahan baku yang paling sering digunakan indutri kecil catering makanan, dimana kelapa proses pengolahannya dilakukan dengan cara diparut [5]. Proses pemarutan kelapa cukup dilakukan dengan manual dengan papan parut sederhana jika berjumlah sedikit, untuk menghasilkan parutan bagus, kecepatan parutan manual yang dibutuhkan kurang lebih 3000 gerakan parut setiap jam, tapi jika daging buah kelapa yang diparut cukup jumlah banyak maka akan menimbulkan kelelahan jika dilakukan dengan cara manual. Mesin parut kelapa kebayakan menggunakan mesin parut bertenaga motor bakar dipasaran, mesin parut bertenaga motor bakar banyak kekurangannya disebabkan beberapa alasan yaitu; harganya yang lebih mahal, memerlukan oil mesin, perawatan harus rutin, menimbulkan kebisingan dan polusi asap. Pada perancangan ini dibuat sebuah alat parut kelapa yang tidak memerlukan perawatan khusus dan tidak bising, mesin parut kelapa ini menggunakan motor listrik dengan daya 220 volt, mudah dibawa, perawatan mudah, mesin tidak mahal dan pemarutan kelapa tidak harus dicungkil hanya dibelah menjadi dua. Jasa pemarut menggunakan mesin parut kelapa bertenaga 1 pk berkapasitas produksi 400 butir/ jam dengan waktu kerja 5 jam 
perhari pada umumnya konsumen membeli daging buah kelapa sekaligus memarutnya dengan biaya sebesar Rp. 4500, untuk harga sebuah daging buah kelapa Rp. 4000 dan biaya pemarutnya Rp.500.

Kelebihan dari mesin pemarut kelapa dengan motor listrik ini biaya perawatan cukup murah dengan pelumasan pada bantalannya setiap minggu, sedangkan perawatan parut motor bakar adalah penggantian pelumas mesin dengan biaya Rp.30.000.

\section{Tinjauan Pustaka}

Dalam tata nama atau sistematika (taksonomi) tumbuh-tumbuhan, tanaman kelapa (cocos nucifera) dimasukan kedalam klasifikasi sebagai berikut tumbuh-tumbuhan, tumbuh berbiji, biji tertutup dan biji berkeping satu. Tanaman kelapa digolongkan ke dalam famili yang sama dengan sagu (metroxylon sp), salak (salaca edulis), aren (arenga pinata), dan lain-lain. Penggolongan varietas kelapa pada umumnya didasarkan pada perbedaan umur pohon mulai berubah bentuk dan ukuran buah, warna buah, serta sifat-sifat kusus yang lain. Kelapa memiliki berbagai nama daerah. Secara umum, buah kelapa dikenal sebagai coconut, orang belanda menyebutnya kokosnoot atau klapper, sedangkan orang prancis menyebutnya cocotier. Di indonesia kelapa biasanya di sebut krambil atau kelapa.[3]

Mesin pemarut kelapa adalah suatu alat yang digunakan untuk membantu atau mempermudah pekerjaan manusia dalam hal pemarutan kelapa. Sumber tenaga utama mesin pemarut adalah tenaga motor, dimana tenaga motor digunakan untuk menggerakkan atau memutar mata parut melalui perantara sabuk (V-belt). Mesin parut kelapa ini mempunyai sistem transmisi berupa puli. Gerak putar dari motor listrik ditransmisikan ke puli 1, kemudian dari puli 1 ditransmisikan ke puli 2 dengan menggunakan sabuk. Ketika motor dihidupkan, maka motor akan berputar kemudian putaran ditransmisikan oleh sabukuntuk menggerakan poros mata parut. Dalam kehidupan sehari-hari kita sering menjumpai mesin pemarut kelapa, biasanya sering kita lihat di pasar-pasar. Mesin parut kelapa yang sudah ada antara lain:

1. Mesin parut dengan menggunakan motor bensin berkapasitas $2 \mathrm{PK}$

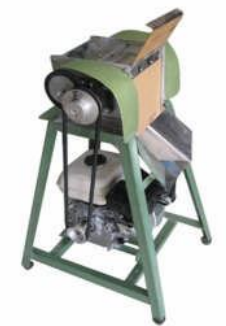

Gambar 1. Mesin parut kelapa motor bensin 2 PK [4]

2. Mesin parut dengan menggunakan motor listrik 0,5 HP.

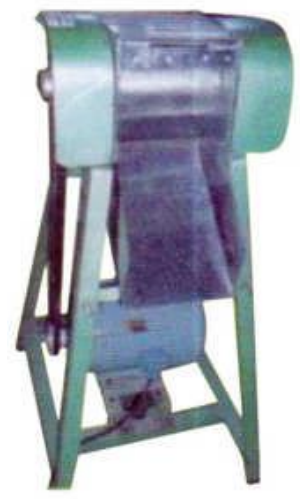

Gambar 2. Mesin parut kelapa motor listrik 125 Watt

Oleh karena itu dalam kesempatan ini perlu dibuat alat pemarut lain yang lebih efisien dan mudah digunakan, dimana konstruksi mesin lebih sederhana bila dibandingkan dengan mesin parut kelapa yang sebelumnya telah dibuat dan beredar di pasaran.

\section{Elemen Mesin}

Elemen mesin merupakan bagian penting dari bidang perancangan mekanis, perancangan menciptakan peralatan atau sistem untuk memenuhi kebutuhankebutuhan khusus. Peralatan mekanis biasanya meliputi komponen-komponen yang bergerak yang mengirimkan daya dan melakukan pola-pola gerak khusus. Tentu saja elemen-elemen mesin tersebut harus sesuai, harus selaras, dan harus bekerja secara aman dan efisien, yang memenuhi kebutuhan konsumen. Perancang harus mempertimbangkan bukan hanya unjuk kerja 
elemen yang di rancang pada suatu waktu tertentu, tetapi juga memikirkan elemenelemen yang akan di padukan [2].

\section{Poros dan Daya Poros}

Poros adalah komponen alat mekanisme yang mentransmisikan gerak berputar dan daya. Poros ini merupakan satu kesatuan dari sebaran sistem mekanis dimana daya ditransmisikan dari penggerak utama, misalnya motor listrik atau motor bakar, ke bagian lain yang berputar dari sistem. Ada beberapa macam sistem mekanisme yang berkaitan dengan elemen berputar yang mentrasmisikan daya. Perhitungan gaya-gaya yang terjadi pada poros dalam proses pemindahan daya:

a). Daya rencana $(\mathrm{kW})$

$$
\mathrm{P} d=f \mathrm{c} \times \mathrm{P}(\mathrm{kW})
$$

Keterangan:

$\mathrm{Pd}$ = Daya yang direncanakan $(\mathrm{kW})$

$F \mathrm{c}=$ Faktor koreksi

$\mathrm{P}$ = Daya yang ditransmisikan

Tabel 1. faktor koreksi daya yang ditransmisikan, fc

\begin{tabular}{|l|c|}
\hline \multicolumn{1}{|c|}{$\begin{array}{c}\text { Daya yang akan } \\
\text { ditransmisikan }\end{array}$} & $F c$ \\
\hline $\begin{array}{l}\text { Daya rata-rata yang } \\
\text { diperlukan }\end{array}$ & $1,2-2,0$ \\
\hline $\begin{array}{l}\text { Daya maksimum yang } \\
\text { diperlukan }\end{array}$ & $0,8-1,2$ \\
\hline Daya normal & $1,2-1,0$ \\
\hline
\end{tabular}

b). Daya poros / daya yang diperlukan (p)

$$
\begin{aligned}
P= & \frac{2 \cdot \pi \cdot N \cdot T}{60} \\
\mathrm{P}= & \text { Daya poros dari poros penggerak pisau } \\
& (\mathrm{kW}) \\
\mathrm{T}= & \text { Torsi }(\mathrm{Nm}) \\
\mathrm{N}= & \text { Putaran }(\mathrm{RPM})
\end{aligned}
$$

c). Torsi (T)

$\mathrm{T}=\mathrm{F} \times \mathrm{d}(\mathrm{Nm})$

$\mathrm{F}$ = Gaya Sentrifugal dari benda berputar / Gaya beban daging kelapa ke mata pisau $(\mathrm{N})$

$\mathrm{D}=$ jarak benda ke pusat rotasi (m) Daya poros / daya yang diperlukan (p)

$$
\begin{aligned}
\mathrm{P}= & \text { Daya poros dari poros penggerak } \\
& \text { pisau }(\mathrm{kW}) \\
\mathrm{T}= & \text { Torsi }(\mathrm{Nm}) \\
\mathrm{N}= & \text { Putaran }(\mathrm{RPM})
\end{aligned}
$$

\section{Metodologi Penelitian}

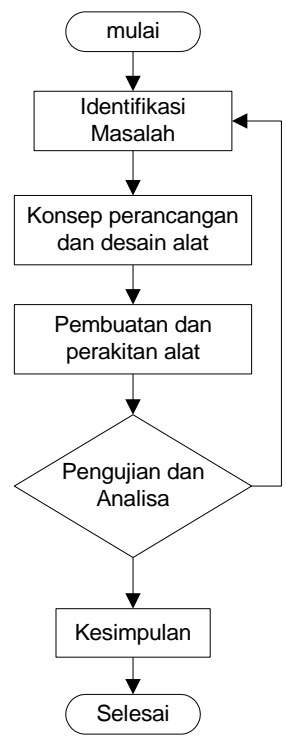

Gambar 3. Diagram alir

\section{Bagian-Bagian Mesin}

Adapun bagian-bagian utama mesin adalah:

1. Motor Listrik

Motor listrik merupakan sumber tenaga penggerak awal dari perancangan mesin ini. Motor listrik bekerja untuk memutar atau menggerakan mata parut.

2. Baskom Penahan

Baskom atau penahan adalah bagian yang digunakan untuk menahan ampas kelapa yang di parut dan sekaligus dinding bagian ini langsung berhubungan dengan alat parut.

3. Mata parut

Mata parut ini terbuat dari pipa almunium , dimana di bagian permukaan sekeliling pipa diukir menjadi seperti paku-paku kecil yang sedemikian rupa sehingga dapat memarut bahan Kelapa.

4. Rangka mesin

Rangka mesin merupakan bagian yang berfungsi untuk menopang seluruh komponenkomponen utama dari mesin pemarut 
Proses Pemarutan Kelapa

1. Siapkan mesin pemarut kelapa

2. Siapkan kelapa yang sudah dibelah.

3. Hidupkan motor

4. Tempelkan belahan kelapa ke mata pisau parut kelapa.

5. Daging buah kelapa akan terparut oleh mata pisau parut

6. Hasil parutan akan keluar dari belahan batok kelapa.

7. Matikan mesin.

\section{Pengolahan data}

\section{Bahan dan Alat Penelitian}

Bahan-bahan yang digunakan adalah kelapa hibrida, stainless steel, besi. Alat-alat yang digunakan pada penelitian ini adalah meteran, baut dan mur, motor listrik, mesin las, mesin bor, mata bor, mesin gerinda, obeng, kunci pas, pisau,, komputer dan alat tulis.

\section{Metode Penelitian}

Dalam penelitian yang dilakukan ini, pengumpulan data dengan cara mencari studi literatur dari penelitian yang telah dilakukan oleh peneliti terdahulu dan dari buku-buku kepustakaan sebagai referensi, kemudian dilakukan perancangan desain, pembuatan, perangkaian pada komponen-komponen alat kelapa parut. Setelah itu dilakukan pengujian pada alat dan pengamatan parameter.

\section{Hasil dan Pembahasan}

Bahan mesin parut kelapa yang digunakan ini akan mempengaruhi kinerja alat yang akan dirancang. Bahan yang digunakan untuk mesin ini harus kokoh dan memenuhi persyaratan yang diinginkan serta mudah diperoleh. Pada alat mesin parut kelapa skala rumah tangga dan industri kecil alat yang digunakan adalah bahan dari plat siku. Pemilihan material untuk kerangka alat pada alat ini terbuat dari besi plat kaena banyak diperoleh dipasaran. Mata pisau di buat dengan bahan dari almunium dan pemasangan mata pisau menggunakan baut dikarenakan mata pisau yang digunakan bisa dibongkar pasang menggantikan mata pisau yang lainnya.

Mata pisau alat pemarut kelapa ini berbentuk bulat yang dipasang pada poros mesin dan dibuat sejajar. Dibuat sejajar pada saat pemarutan kelapa yang di belah menjadi dua dapat terparut. Mata pisau terbuat dari almunium berbentuk bundar dengan diametr $10 \mathrm{~mm}$ berbentuk bulat. Pemasangan mata pisaunya dapat dilakukan dengan bongkar pasang yaitu, dengan mengunci menggunakan baut. Dibuat bongkar pasang bertujuan agar memudahkan saat pergantian mata pisau dan perawatan.

Tenaga yang dihasilkan oleh motor listrik adalah sebesar 1 HP buah kelapa tua yang dapat diparut dalam sekali operasi bisa beberapa buah kelapa. Hal ini terjadi karena tenaga yang dihasilkan oleh motor listrik tersebut mencukupi untuk pemarutan buah kelapa lebih dari satu dan juga karena sistem pemarutannya langsung dari batok kelapa.

Parutan kelapa ini dilengkapi dengan baskom penahan yang bertujuan untuk menahan parutan buah kelapa agar tidak keluar kemana-mana akibat dari perputaran mata pisau parut kelapa yang berputar, penahan (baskom) ini terbuat dari bahan stainlees steel.

\section{Pengujian Mesin}

Setelah dilakukan proses perancangan dan proses pembuatan mesin parut kelapa maka langkah selanjutnya adalah melakukan uji kinerja mesin tersebut. Uji kinerja ini bertujuan untuk mengetahui kinerja mesin, sesuai atau tidak dengan konsep perancangan.

1. Bahan yang diperlukan untuk pengujian mesin:

a. Satu buah kelapa dengan diameter luar 130 $\mathrm{mm}$ dan dibelah menjadi dua, dengan tujuan agar lebih mudah dalam pemarutan.

b. 1 kg kelapa

c. Stopwatch

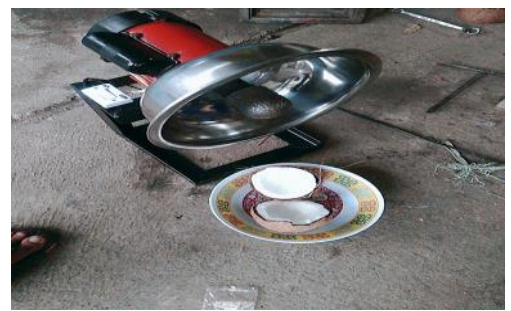

Gambar. 1 Mesin dan kelapa yang dibelah menjadi dua bagian 
2. Prosedur pengujian

Mesin dinyalakan kelapa yang sudah di belah menjadi dua ditempelkan pada mata pisau.

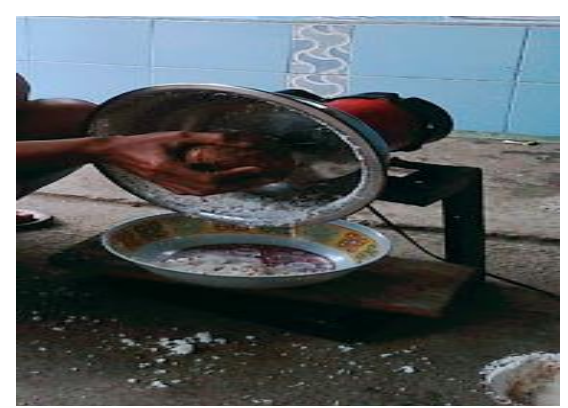

Gambar 2. Proses Pemarutan

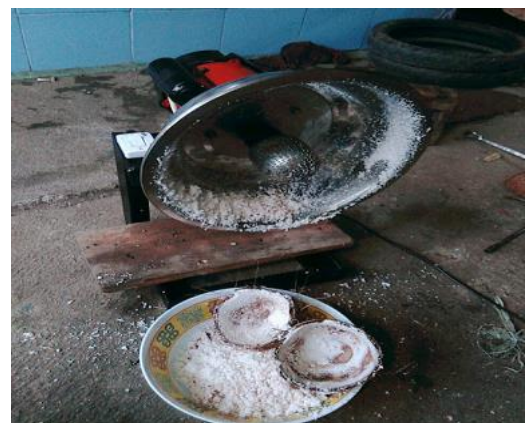

Gambar 3. Hasil Proses Pemarutan kelapa

3. Hasil Pengujian

Berdasarkan hasil uji kinerja mesin dapat diambil kesimpulan bahwa:

a. Untuk memarut satu buah kelapa yang berdiameter luar $130 \mathrm{~mm}$ dan tebal 12 mm diperlukan waktu selama 4 menit 4 detik.

b. Untuk memarut $1 \mathrm{~kg}$ kelapa diperlukan waktu selama 9,78 menit.

4. Kelebihan dan kekurangan mesin kelapa parut

a. Tingkat kebisingan sangat rendah dan getaran dapat diabaikan.

b. Kenaikan suhu motor selama 2 jam sampai 4 jam dioperasikan, tidak terjadi kenaikan suhu motor.

c. Putaran kepala parut cukup baik, hanya saja pemarutan kelapa yang ada batoknya tidak bersih, sehingga pengoprasian pemarutan harus disesuaikan besaran kelapa.

d. Mesin mudah dibawa dan aman untuk digunakan.
5. Perhitungan daya motor

Poros merupakan merupakan komponen dari mesin parut kelapa yang memiliki peran penting dalam sistem trasmisi, poros ini berfungsi sebagai pemutar mata parut dan sebagai dudukan mata parut. Poros penggerak ini berbentuk silinder dengan ukuran diameter: $10 \mathrm{~mm}$, dan panjang: $180 \mathrm{~mm}$. Bahan poros pada mesin parut ini menggunakan baja S $45 \mathrm{C}$ dengan kekuatan tarik $58 \mathrm{~kg} / \mathrm{mm}^{2}$

Daya motor yang gunakan adalah 1 phase dimana sudah diketahui kW dan Amperenya jika hanya diketahui $\mathrm{kW}$-nya saja bagaimana menghitungnya:

Diket:

$\mathrm{P}: 8 \mathrm{~kW}=\mathrm{x} 1000=8000 \mathrm{Watt}$

$\mathrm{V} \quad: 220$ Volt

Dengan rumus daya motor 1 phase

$\mathrm{P} \quad=\mathrm{VxI}$

I $=\mathrm{P} / \mathrm{V}$

Ket:

P : Daya (Watt)

I : Arus (Ampere)

$\mathrm{V}$ : Tegangan (Voltage)

$\mathrm{I}=\mathrm{P} / \mathrm{V}$

I $=8000 / 220$

$\mathrm{I}=36.36 \mathrm{~A}$

Power motor yang tersedia $=1.000 \mathrm{~kW}$, karena power motor masih lebih besar dari daya rencana poros maka power motor yang digunakan masih aman.

\section{Pemeliharaan Alat}

Secara umum alat ini tidak membutuhkan pemeliharaan secara khusus. Namun untuk mendapatkan fungsi yang maksimal selama umur pemakaian, maka pemeliharaan terhadap komponen-komponen yang mendukung alat ini mutlak diperlukan pemeliharaan yang dimaksud adalah sebagai berikut:

1. Untuk menghindari bau tak sedap, bersihkan bak penahan (Corong) dengan air setelah proses pemarutan kelapa selesai dilakukan.

2. Untuk mencegah terjadinya proses pengkorosian pada komponen tertentu, lumasilah bagian-bagian yang bergerak 
atau membutuhkan pelumasan dengan minyak pelumas.

3. Bersihkan alat dari debu-debu dan kontaminan lainnya yang mengganggu proses pengoperasian.

4. Lakukan pemeliharaan secara berkala.

\section{Kesimpulan dan Saran}

Kesimpulam

Hasil perancangan mesin parut kelapa adalah sebagai berikut:

1. Spesifikasi mesin, panjang: $55 \mathrm{~mm}$, lebar: $30 \mathrm{~mm}$, tinggi: $45 \mathrm{~mm}$.

2. Pengerak utama mesin parut kelapa menggunakan motor listrik 1 phase dan daya 220 volt.

3. Sistem transmisi menggunakan poros pisau mata parut.

4. Kinerja mesin parut kelapa yang sudah dibelah menjadi dua bagian, untuk memarut satu buah kelapa yang berdiameter luar $130 \mathrm{~mm}$ diperlukan waktu 3 menit 4 detik, dan untuk memarut $1 \mathrm{~kg}$ kelapa diperlukan waktu 9,78 menit.

Saran

Proses penyempurnaan mesin masih diperlukan untuk meningkatkan kualitas mesin, usulan perbaikan rancangan mesin antara lain:

1. bahan teknik untuk kontruksi menggunakan bahan yang bagus supaya tahan terhadap karat dan koros.

2. Penahan ampas kelapa atau corong gunakan yang agak lonjong agar hasil pemarutan kelapa tidak berceceran.

3. Pada saat pembersihan penahan atau corong setelah penggunaan sebaiknya menggunakan kain yang bersih dan kering, jangan menggunakan air.

\section{Daftar Pustaka}

[1]. Suhardiyono, L. 1987. Tanaman Kelapa. Kanisius. Yogyakarta.

[2]. Sularso, Dasar Perencanaan dan Pemilihan Elemen Mesin, Jakarta : Pradya Paramita 1983.
[3]. Dobrovolsky, V. "Machine Elements". Stolk, Jac. "Elemen Mesin", Erlangga, 1981.

[4]. Maiseka Leu, M.A. Coward David, M.A. Marshall Craig. Alat Pemarut Kelapa dan Singkong.

[5]. SERI BUKU PENGEMBANGAN MASYARAKAT DESA. Program Kerjasama DINSOSNAKERTRANSSIL Edisi Ketiga. 2004 